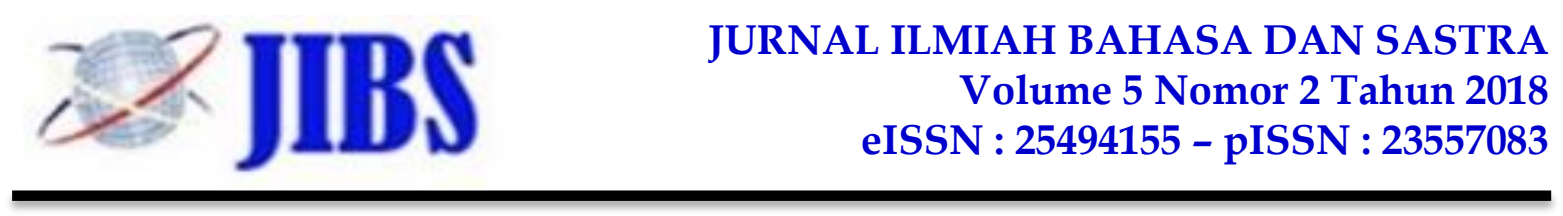

\title{
PENINGKATAN KEMAMPUAN MENULIS DESKRIPSI DENGAN METODE OBSERVASI TERPADU SISWA KELAS X SMK PGRI PAKISAJI MALANG
}

\author{
Ina Roudhotul Jannah \\ inaroudhotul@yahoo.com
}

\begin{abstract}
Abstrak
Menulis merupakan suatu keterampilan berbahasa yang dipergunakan untuk berkomunikasi secara tidak langsung dan tidak secara tatap muka dengan orang lain. Keterampilan menulis tidak datang dengan sendirinya, hal itu menuntut latihan yang cukup dan teratur. Penelitian ini mengkaji tentang permasalahan kemampuan peserta didik dalam menulis karangan deskripsi dengan menggunakan metode pembelajaran observasi terpadu. Kurangnya kemampuan peserta didik dalam menulis deskripsi disebabkan oleh kurangnya minat peserta didik untuk belajar, guru masih menggunakan metode yang tradisional, dalam pembelajaran menulis guru hanya memberikan teori tanpa diberikan praktek menulis terutama menulis deskripsi. Penggunaan metode observasi terpadu terbukti mampu meningkatkan kemampuan menulis deskripsi peserta didik. Hal tersebut dapat diketahui dengan memberikan tes menulis dekripsi kepada peserta didik. Dengan pembelajaran observasi terpadu, peserta didik mampu menuangkan ide dan gagasan ke dalam tulisan deskripsi dengan hasil observasi yang dilakukan selama pembelajaran berlangsung. Observasi dilakukan di luar ruang kelas dan hanya disekitar lingkungan sekolah serta halaman belakang sekolah, sehingga peserta didik mempunyai banyak ide cemerlang untuk mendapatkan hasil karangan yang baik.
\end{abstract}

Kata Kunci: Peningkatan, menulis, deskripsi, metode observasi terpadu.

\begin{abstract}
Writing is a skill that language is used to communicate indirectly and not face-to-face with other people. Writing skills do not come naturally, but it requires adequate exercises. This study examines the learners' problems in essay writing descriptions using the integrated observation learning methods. The lack of ability of the students in writing a description is due to lack of interest of students to learn, teachers' traditional methods in teaching, and the theory - oriented activities without practice writing especially writing descriptions. The use of an integrated observation method proved to increase the ability of students to write descriptions. It can be taken from the test given to the students to write desciptions. With integrated observation learning, learners are able to generate ideas into writing descriptions by conducting an observation during the learning takes place. Observation was done outside of the classroom and school environment as well as just around the backyard of the school, so the students have a lot of good ideas to compose a good essay.
\end{abstract}

Keywords: Improved, writing, descriptions, integrated observation method.

\section{PENDAHULUAN}

Menulis merupakan suatu keterampilan berbahasa yang dipergunakan untuk berkomunikasi secara tidak langsung dan tidak secara tatap muka dengan orang lain. Dalam kegiatan menulis, penulis harus terampil memanfaatkan sistem tulisan, struktur bahasa, dan kosa kata. Keterampilan menulis tidak datang dengan sendirinya, hal itu menuntut latihan 
yang cukup dan teratur. Kemampuan menulis melatih peserta didik untuk berpikir secara sistematis, rasional, dan ilmiah, sehingga diharapkan dapat mempengaruhi prestasi belajar.

Alasan peneliti mengambil judul ini, yaitu bahwa proses pembelajaran yang dilaksanakan di SMK PGRI Pakisaji selama ini masih konvensional dan kurangnya kemampuan peserta didik dalam menulis paragraf deskripsi. Hal ini diperoleh dari hasil wawancara dengan guru mata pelajaran yang diantaranya, (1) di SMK PGRI Pakisaji pembelajaran menulis hanya di fokuskan pada penjelasan teori yang telah ada,

(2) kemampuan peserta didik dalam mengembangkan ide-ide pokok masih sangat kurang, peserta didik lebih sering mencontek hasil karya sesorang yang ada di buku atau di internet daripada mengolah ide-ide cemerlang, (3) peserta didik juga kurang berminat dalam pembelajaran menulis terutama pembelajaran menulis deskripsi, (4) dalam pembelajaran menulis deskripsi, guru merasa kesulitan dalam pengambilan metode apa yang cocok untuk membelajarkan peserta didik, (5) pada pembelajaran yang dirasa sulit oleh peserta didik, peserta didik jarang menanyakan kepada guru maupun bertanya kepada temannya, dan (6) setiap guru bertanya kepada keseluruhan peserta didik, selalu saja hanya peserta didik yang pandai yang menjawab pertanyaan guru tersebut sedangkan yang lainnya jarang sekali ikut menjawab atau hanya duduk diam di bangku saja.

Berdasarkan penjelasan yang diuraikan diatas, rumusan masalah pada penelitian ini yaitu bagaimanakah peningkatan kemampuan menulis deskripsi melalui metode pembelajaran observasi terpadu siswa kelas X SMK PGRI Pakisaji?

Berdasarkan rumusan masalah diatas, tujuan dari penelitian yang akan dilakukan adalah untuk mendeskripsikan peningkatan kemampuan menulis deskripsi melalui metode pembelajaran observasi terpadu pada siswa kelas X SMK PGRI Pakisaji Malang.

Dari tujuan yang telah dijelaskan, penelitian ini diharapkan dapat meberikan manfaat yang positif baik bagi pihak sekolah, guru, maupun bagi pihak yang di teliti atau peserta didik.

Menulis, seperti juga halnya ketiga keterampilan berbahasa lainnya, merupakan suatu proses perkembangan. Menulis menuntut pengalaman, waktu, kesempatan, pelatihan, keterampilan-keterampilan khusus, dan pengajaran langsung menjadi seorang penulis. Menuntut gagasan-gagasan yang tersusun secara logis, diekspresikan dengan jelas, dan ditata secara menarik. Selanjutnya menuntut penelitian yang terperinci, observasi yang seksama, pembedaan yang tepat dalam pemilihan judul,bentuk dan gaya (Tarigan, 2008: 89).

Keterampilan menulis tidak datang dengan sendirinya. Hal itu menuntut latihan yang cukup dan teratur serta pendidikannya yang berprogram. Biasanya, program-program dalam bahasa tulis direncanakan untuk mencapai tujuan-tujuan untuk mendorong peserta didik mengekspresikan diri secara bebas dalam tulisan (Tarigan, 2008:9).

Dalam membuat sebuah tulisan, diperlukan beberapa unsur yang harus diperhatikan. Menurut Gie, 2002 (dalam Nurudin, 2007: 5), unsur menulis terdiri atas gagasan, tuturan (narasi, deskripsi, eksposisi, argumentasi, dan persuasi), tatanan, dan wahana. Dalam hal ini, peneliti mengkaji tentang penulisan paragraf deskripsi. Adapun pengertian deskripsi yaitu tulisan yang bersifat menyebutkan karakteristik-karakteristik suatu objek secara keseluruhan, jelas, dan sistematis. Tompkins (dalam Zainurrahman, 2011:45) menyebutkan bahwa tulisan deskripsi adalah tulisan yang seperti "melukis sebuah 
gambar dengan menggunakan kata-kata".

(1) Isi

Unsur-unsur yang terdapat dalam paragraf deskripsi yaitu berikut.

Dalam paragraf deskripsi, isi merupakan aspek penilaian. Isi mencakup topik dan urutan pengembangannya.

(2) Organisasi Isi

Organisasi isi dalam paragraf adalah mengolah bahan, mengaturnya, mengembangkannya serta menyusunya dalam struktur yang logis.

(3) Diksi/ Pilihan Kata

Dalam Kamus Besar Bahasa Indonesia, diksi adalah pilihan kata yang tepat dan selaras (dalam penggunaanya) untuk mengungkapkan gagasan sehingga diperoleh efek tertentu (seperti yang diharapkan).

\section{(4) Impresionisme}

Paragraf deskripsi impresionisme memperlihatkan dua hal. Pertama adanya objek yang dilukiskan. Kedua, adanya rincian terhadap objek yang dilukiskan. Objek yang dilukiskan dari rincian tersebut akan memperlihatkan sebuah paragraf deskripsi yang menarik.

Langkah-langkah dalam menulis paragraf deskripsi, yaitu (1) menentukan tema; (2) menetapkan tujuan penulisan; (3) mengumpulkan bahan; (4) membuat kerangka karangan; (5) mengembangkan kerangka karangan; dan (6) merevisi karangan.

Metode yang peneliti gunakan dalam penelitian ini yaitu dengan menggunakan metode observasi terpadu. Menurut Prabowo (dalam Ahmadi, 2011:44-45), pembelajaran terpadu merupakan pendekatan belajar mengajar yang melibatkan beberapa bidang studi. Pendekatan belajar mengajar seperti ini diharapkan akan dapat memberikan pengalaman yang bermakna terhadap peserta didik.

Menurut Dekdikbud (dalam Trianto, 2007:13-14), pembelajaran terpadu mempunyai beberapa kakteristik atau ciri-ciri, yaitu (1) Holistik, (2) Bermakna,

(3) Otentik, dan (4) Aktif.

Prinsip-prinsip dalam pembelajaran terpadu menurut Trianto (2007: 8-10), yaitu meliputi : (1) prinsip penggalian tema,

(2) prinsip pelaksanaan pembelajaran terpadu, (3) prinsip evaluasi, dan (4) prinsip reaksi.

Langkah-langkah pembelajaran terpadu menurut Prabowo (dalam Trianto, 2007: 15) mengikuti tahap-tahap yang dilalui dalam setiap model pembelajaran yang meliputi tiga tahap, yaitu tahap perencanaan, tahap pelaksanaan, dan tahap evaluasi.

\section{METODE PENELITIAN}

Penelitian ini digolongkan ke dalam jenis Penelitian Tindakan Kelas (PTK). Penelitian tindakan kelas merupakan proses pengkajian melalui sistem berdaur atau siklus dari berbagai kegiatan pembelajaran.

Penelitian ini menggunakan PTK dengan desain penelitian menggunakan 2 siklus dengan alur penelitian tindakan kelas yang diawali dengan tahap perencanaan, pelaksanaan, observasi, dan refleksi (Arikunto, $2010: 74$ ) 


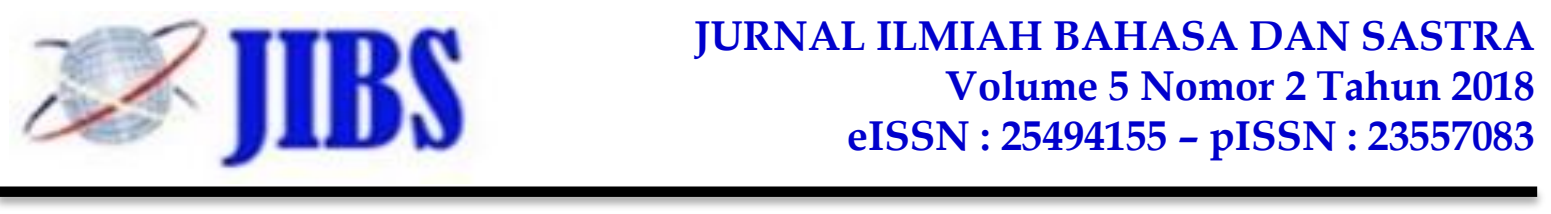

Kegiatan ini dilakukan oleh peneliti pada saat kegiatan pembelajaran di kelas X. Peneliti mengambil seting penelitian di SMK PGRI Pakisaji Malang.

Peneliti menggunakan data hasil wawancara, lembar observasi, catatan lapangan, dokumentasi, dan lembar penilaian menulis. Sumber data penelitian ini adalah siswa kelas X SMK PGRI Pakisaji Malang dengan jumlah 24 siswa yang terdiri dari 8 siswa laki-laki dan 16 siswi perempuan.

Instrumen yang digunakan dalam penelitian ini berupa tes dan nontes. Instrumen yang berupa tes terdiri dari RPP (rencana pelaksanaan pembelajaran), tes menulis deskripsi, dan lembar penilaian, sedangkan nontes terdiri dari dokumentasi, observasi, dan wawancara.

Teknik pengumpulan data dalam penelitian ini adalah dengan mengamati setiap aktivitas peserta didik yang termasuk dalam indikator menulis karangan deskripsi.

Teknik analisis data dalam penelitian kualitatif dilakukan sejak sebelum memasuki lapangan, selama di lapangan, dan setelah selesai di lapangan. Data kualitatif berupa hasil dokumentasi tugas siswa, catatan lapangan, dan wawancara. Data kuantitatif diperoleh dari hasil tes awal dan dari hasil tes akhir.

\section{HASIL PENELITIAN DAN PEMBAHASAN}

\section{A. Hasil Penelitian}

Informasi awal pengetahuan dan keterampilan peserta didik menulis deskripsi diperoleh dari hasil wawancara dengan guru dan juga dari hasil menulis deskripsi peserta didik pada tahap prasiklus. Hasil tes awal menunjukkan bahwa bahwa keberhasilan keterampilan menulis deskripsi peserta didik masih kurang. Kesulitan peserta didik dalam menemukan dan menuangkan ide ketika menulis deskripsi salah satunya dipengaruhi oleh ketidakbiasaan peserta didik dalam latihan menulis deskripsi.

Pelaksanaan penelitian tindakan kelas dalam pembelajaran menulis deskripsi dengan metode pembelajaran observasi terpadu siswa kelas XC SMK PGRI Pakisaji Malang dilaksanakan dalam dua siklus.

(1) Perencanaan Siklus I

Tahap perencanaan dilakukan setelah dan sebelum tindakan diberikan kepada peserta didik.

(2) Pelaksanaan Siklus I

Pelaksanaan tindakan dengan penerapan model observasi terpadu diharapkan dapat meningkatkan keterampilan menulis deskripsi siswa kelas XC SMK PGRI Pakisaji Malang.

(3) Pengamatan Siklus I

Hal yang diamati dari situasi belajar mengajar adalah perilaku positif dan negatif peserta didik terhadap perhatian, partisipasi, respon, dan keaktifan peserta didik dalam pembelajaran menulis deskripsi.

(4) Hasil Penelitian Siklus I

Hasil belajar dalam penelitian ini diperoleh dari hasil analisis tugas peserta didik yang diberikan oleh peneliti saat pelaksanaan tindakan siklus I. Hasil penilaian siklus I diperoleh dari tugas menulis deskripsi peserta didik dengan metode observasi terpadu. Hasil tes menunjukkan dari jumlah keseluruhan nilai siswa, dapat diperoleh nilai rata-rata 
kemampuan menulis deskripsi peserta didik siklus I adalah 73,33\%, sedangkan nilai ratarata prasiklus adalah $66,7 \%$. Nilai rata-rata tersebut menandakan adanya peningkatan sebesar $6,63 \%$ dari nilai prasiklus.

\section{(5) Refleksi Siklus I}

Peneliti bersama kolabolator melakukan refleksi untuk perbaikan tindakan pada tahap berikutnya. Refleksi ini dilakukan secara bertahap dan berulang untuk memperbaiki dan menyempurnakan kegiatan yang telah dilakukan sebelumnya.

Siklus II terbagi menjadi dua kali pertemuan yang dilaksanakan pada hari Kamis, 24 April 2014 dan hari Jumat, 25 April 2014. Penelitian tindakan kelas siklus II dilakukan sebagai strategi dalam upaya peningkatan kemajuan menulis deskripsi. Adapun prosedur tindakan pada siklus ini sebagai berikut.

\section{(1) Perencanaan Siklus II}

Tahap perencanaan pada siklus II merupakan penyempurnaan dari perencanaan siklus I dengan menyusun perbaikan rencana pembelajaran keterampilan menulis paragraf deskripsi dengan metode observasi terpadu.

(2) Pelaksanaan Siklus II

Tahap pelaksanaan pada siklus II ini merupakan perbaikan dari tahap tindakan pada siklus I, dengan langkah-langkah yang sama dengan siklus I.

\section{(3) Pengamatan Siklus II}

Pengamatan yang dilakukan pada tahap siklus II ini difokuskan pada situasi kegiatan belajar peserta didik. Hal yang diamati dari situasi kegiatan belajar peserta didik adalah aktivitas belajar, perhatian, keaktifan, dan proses belajar.

\section{(4) Hasil Penelitian Siklus II}

Hasil tindakan siklus II menunjukkan adanya peningkatan dibandingkan hasil siklus sebelumnya, baik dari keterampilan peserta didik dalam menulis deskripsi maupun skor rata-rata. Perolehan skor rata-rata keterampilan menulis deskripsi pada siklus II adalah $87,71 \%$. Skor rata-rata tersebut menandakan adanya peningkatan sebesar $14,38 \%$ dari skor rata-rata siklus I.

\section{(5) Refleksi Siklus II}

Setelah dilakukan tindakan-tindakan mulai dari prasiklus, siklus I sampai siklus II, peneliti dan kolabolator melakukan evaluasi terhadap semua tindakan yang sudah dilakukan. Berdasarkan hasil diskusi antara peneliti dan kolabolator, penerapan metode observasi terpadu dalam praktik menulis deskripsi menunjukkan peningkatan kemampuan hasil yang cukup berarti.

\section{B. Pembahasan Penelitian Tindakan Kelas}

Sesuai dengan metode yang dipakai, pembahasan mengenai penerapan metode pembelajaran observasi terpadu dalam menulis deskripsi dibedakan atas pembahasan prasiklus, pembahasan siklus 1, dan pembahasan siklus 2 .

(1) Sebelum Tindakan (Prasiklus)

Dari tahap prasiklus, peneliti memberikan tes awal kepada peserta didik. Berdasarkan hasil menulis deskripsi pada tahap prasiklus, diketahui bahwa keterampulan peserta didik kelas 
X SMK PGRI Pakisaji Malang masih kurang. Peserta didik masih kurang terampil mengembangkan karangan deskripsi, dan masih banyak kesalahan dalam penulisan. Peneliti memperoleh data hasil tes awal berupa rata-rata skor sebesar $(16,6 \%)$ dari jumlah keseluruhan peserta didik 24 siswa dengan kategori masih kurang dan perlu ditingkatkan. Hasil tes awal tersebut, peneliti memberikan tindakan pada tahap siklus I.

(2) Tindakan Pertama (Siklus I)

Dalam tindakan siklus I, pembelajaran menulis deskripsi dilakukan dengan menerapkan metode pembelajaran observasi terpadu. Peneliti menjelaskan prosedur penerapan metode observasi terpadu yang digunakan dalam menulis deskripsi. Hasil yang diperoleh dari tindakan siklus I, yaitu dengan pemberian tugas menulis karangan deskripsi dengan tema lingkungan sekitar sekolah. Untuk tes evaluasi siklus I diperoleh hasil rata-rata nilai kemapuan menulis deskripsi peserta didik sebesar (50\%) dari jumlah keseluruhan 24 siswa dengan kategori cukup dan perlu adanya perbaikan pada tindakan selanjutnya yaitu siklus II.

\section{(3) Tindakan Kedua (Siklus II)}

Siklus II merupakan usaha perbaikan dari siklus I. Usaha perbaikan ini menyangkut hal-hal mengenai pelaksanaan yang belum sepenuhnya sempurna. Siklus II dilaksanankan untuk lebih meningkatkan lagi kemampuan menulis deskripsi pada peserta didik. Hasil yang diperoleh dalam siklus II menunjukkan bahwa keberhasilan peserta didik meningkatkan kemampuan menulis deskripsi dengan metode observasi terpadu. Tingkat keberhasilan mencapai $87,50 \%$ dengan pencapaian nilai dengan rentangan 81-90, dengan nilai ketuntasan minimal 75 .

\section{Tingkat Keberhasilan Tindakan}

Tingkat keberhasilan tindakan ini dapat dilihat pada tingkat perkembangan kemampuan menulis deskripsi dengan tindakan-tindakan yang telah dilakukan pada penelitian ini.

\section{SIMPULAN}

Berdasarkan hasil penelitian dan pembahasan, dapat disimpulkan bahwa kemampuan menulis deskripsi peserta didik kelas X SMK PGRI Pakisaji Malang dapat ditingkatkan dengan metode pembelajaran observasi terpadu.

Peningkatan hasil kemampuan menulis deskripsi peserta didik dapat dilihat dari perbandingan nilai rata-rata menulis deskripsi pada tahap prasiklus sampai dengan tahap siklus II. Nilai rata-rata menulis deskripsi peserta didik pada tahap prasiklus sebesar 66,7\%. Nilai rata-rata menulis deskripsi pada siklus II sebesar 87,29\%. Jadi, terjadi peningkatan nilai rata-rata sebesar $20,59 \%$.

Berdasarkan hasil penelitian dan pembahasan dapat ditarik kesimpulan bahwa penggunaan metode observasi terpadu dalam pembelajaran menulis deskripsi dapat meningkatkan kemampuan menulis deskripsi peserta didik. Siswa sudah mulai tertarik dengan pembelajaran menulis deskripsi, mereka lebih bersemangat untuk mengikuti pelajaran dan memperoleh pengetahuan, selain itu dengan menggunakan metode observasi terpadu, siswa 


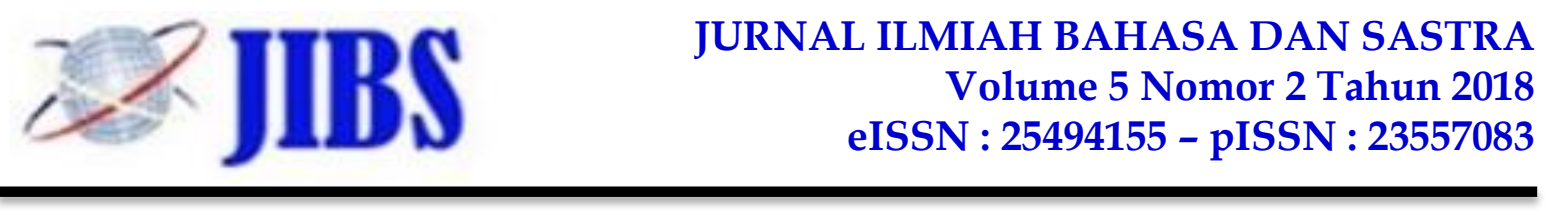

merasa bahwa pembelajaran yang sedang berlangsung merupakan pembelajaran yang menyenangkan dan penuh inspirasi untuk menuangkan pikiran dan pendapat.

\section{SARAN}

\section{(a) Untuk Guru Mata Pelajaran Bahasa Indonesia}

Penerapan metode pembelajaran observasi terpadu adalah solusi yang telah terbukti dapat meningkatkan pembelajaran menulis deskripsi di SMK PGRI Pakisaji Malang. Pembelajaran dengan menerapkan metode observasi terpadu dapat lebih meningkatkan keaktifan siswa, menambah rasa percaya diri siswa dalam berinteraksi dan mengemukakan pendapatnya, serta membantu siswa lebih mudah menemukan ide-ide, juga terus memberikan latihan praktik menulis karangan supaya peserta didik lebih bisa berkreasi dan lebih terampil dalam menulis karangan deskripsi dan pembelajaran menulis lainnya.

(b) Untuk Peserta Didik

Penerapan metode observasi terpadu untuk peserta didik yang telah berhasil meningkatkan kemampuan menulis deskripsi yang sudah baik, yang telah dicapai harus dipertahankan dan dikembangkan terus, dan juga diharapkan agar peserta didik terus berlatih dalam menulis karangan dengan lebih meningkatkan kemampuan menuangkan ide dan gagasan ke dalam sebuah tulisan.

(c) Untuk Peneliti Selanjutnya

Untuk peneliti selanjutnya yang tertarik meneliti dengan metode observasi terpadu untuk meningkatkan kemampuan menulis deskripsi ini masih perlu dilakukan, terutama pada pembelajaran menulis yang lain. Selain itu, penggunaan metode observasi terpadu memberikan motivasi kepada peserta didik untuk lebih termotivasi lagi dalam pembelajaran menulis lainnya terutama pembelajaran mengarang.

\section{DAFTAR RUJUKAN}

Arikunto. Suharsimi, Suhardjono, dan Supardi. 2010. Penelitian Tindakan Kelas. Jakarta : PT Bumi Aksara.

Fauzi, Ilham. 2013. Karangan Deskripsi dan Narasi. (Online). http://weloveblitar.blogspot.com/2013/02/karangan-deskripsi-dan-narasi.html/ dikases pada tanggal 22 Februari 2013.

Fitri Hutagalung, Erny. 2012. Menulis. (Online). http://menulisalaerny.blogspot.com/ $\begin{array}{lllll}\text { diakses } & \text { pada } & \text { tanggal } & 27 & \text { Oktober }\end{array}$ http://www.sekolahdasar.net/2012/04/tujuan-dan-jenis-jenismenulis.html\#ixzz2v3fNnaHw

Nurudin. 2007. Dasar-dasar Penulisan. Malang : UMM Press 
Tarigan, Henry Guntur. 2008. Menulis Sebagai Suatu Keterampilan berbahasa. Bandung : Angkasa.

Zainurrahman. 2011. Menulis : Dari Teori Hingga Praktik (Penawar Racun Plagiarisme). Bandung : Alfabeta. 